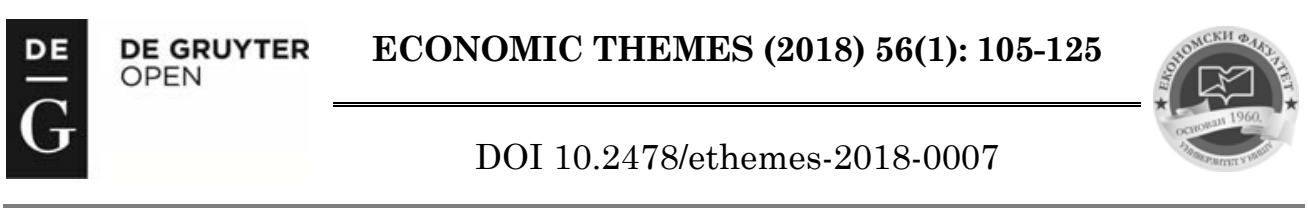

\title{
THE RESOURSE VALORISATION OF AUTHENTIC TOURIST OFFER OF WESTERN SERBIA
}

\section{Aleksandar Gligorijević}

State Audit Institution, Belgrade, Republic of Serbia

\gligorijevic@gmail.com

\section{Milan Novović}

Business School of Vocational Studies, Belgrade, Republic of Serbia

$\bowtie$ milan.novovic@vpscacak.edu.rs

UDC

338.488

(497.11)

Review paper

Received:

15.12.2017

Accepted:

27.03.2018

\begin{abstract}
In recent decades, from a global scale aspect, tourism demand is becoming more differentiated. On one hand, a preserved natural environment and clean air are demanded, while, on the other hand, a growing number of tourists want to travel and see cultural and historical heritage of the area in which they are spending their holiday. In order to compete in the world tourist market, an area must possess various and extensive resources. Therefore, new destinations that, above all, have a rich original tourist offer are required. Since Western Serbia has significant natural and anthropogenic resources, this paper explores its original tourist potential. In this sense, with the use of modern methodologies for evaluating the still untapped potential tourist area, this paper presents an approach to valorisation, both natural and anthropogenic resources of Western Serbia. The research aims, through this evaluation, to show how, in what way these resources can be placed in the function of tourism exploitation and greater involvement of Western Serbia in contemporary touristic trends.
\end{abstract}

Keywords: tourism, offer, Western Serbia, resource.

JEL classification: R11, C10, L83, Q26

\section{Introduction}

Tourist offer is a very broad term, which in economic vocabulary, means the quantity of goods and services offered to tourists at a certain tourist market, at a 
certain time for a certain price (Gligorijević, Stefanović, 2010). In economic theory, there are two main parts of the tourist offer, namely: the original (primary) and derived (secondary) tourism offer. The first part of tourist offer includes attractive characteristics - natural characteristics, environment, cultural-historical inheritance, etc, while another part relates to the organized economic activity of a number of entities providing the required services and tourism products.

The original component of the tourist offer on the market does not appear independently and directly, but rather indirectly through derivative deals, participating in primary market flows and this is called the conversion feature of tourism: the ability to convert and include intangible assets in the market relations and flows.

Starting from the opinion of some authors that for the purposes of analysis, an area(a part of territory) of a country can be selected, which according to certain criteria (functional, structural, development, etc.) corresponds to the purpose of analysis that is carried out, wherein the various approaches are possible (the existing territorial division can be used or a new division can be made) (Aranđelović, Gligorijević, 2014, 85) as well as the fact that there is adequate statistical body, our commitment is that the region of Western Serbia is composed of four areas (Mačva, Kolubara, Zlatibor and Moravica).

\section{Research methodology}

The modern tourist movements are directed towards new attractive and unsaturated areas, which requires a new redistribution of the space according to sources of tourist demand. In recent decades, in the study of unused tourism area, an econometric models are increasingly being used. These models and their findings should not be taken as the basis of a comprehensive tourist value of an area, because the value of a receptive area depends on the socio-economic characteristics of the country (political situation, economic system, culture, tradition, etc.). These models are based on the evaluation of natural attractions, important for tourism development (relief, hydrography, flora and climate). These are the following models (Milenković, 1999, 44; Milenković, 2000, 54, Warszynska, 1974): (1) the coefficient of tourist attractiveness of relief - $K_{h}$; (2) the coefficient of tourist attractiveness of hydrographic potential $-K_{w}$; (3) the coefficient of tourist attractiveness of vegetation - $K_{l}$; and (4) assessment of climate: (a) index of the attractiveness of the winter season $-K_{z}$ and (b) the index of attractiveness of summer time - $I$.

(1) The coefficient of the tourist attractiveness of the relief starts from the following form: 


$$
K_{h}=\left(\frac{H_{i}}{H_{m}}\right)^{\frac{1}{h} \cdot \frac{H_{w}-H_{W i}}{H_{w}}}, \text { meaning } \log K_{h}=\left(\frac{H_{i}}{H_{m}}\right) \log \frac{1}{h} \cdot \frac{H_{w}-H_{w i}}{H_{w}}
$$

wherein:

$H_{i}$ - maximum height of the observed tourist site;

$H_{m}$ - the maximum height of the region, or some larger area in which the analysed site is located;

$H_{w}$ - the maximum or minimum difference between the highest and the lowest points in that region;

$H_{w i}$ - maximum or minimum difference of the highest and lowest points of the tourist place and

$h$ - the intensity of the division of relief, whose value ranges from 1 to $5 .^{1}$

Coefficient of attractiveness of the relief has the following border values: if $K_{h}=1$, a relief that enables development of tourism, but with a simple reproduction; if $K_{h}>1$, in these forms of relief, a tourist industry should not be developed, because it will be uneconomical due to the influence of negative factors and if $K_{h}<1$, in this area it is necessary to develop tourism, as it will be profitable due to the positive effects of the relief.

(2) The coefficient of tourist attractions hydrographic potential has the following model:

$$
K_{w}=c\left(\frac{Q_{i}}{Q_{w}}\right)^{r \cdot \frac{F_{c i}-F_{w i}}{F_{c i}}}, \text { meaning, } \log K_{w}=c \frac{Q_{i}}{Q_{w}} \cdot \log r \cdot \frac{F_{c i}-F_{w i}}{F_{c i}}
$$

wherein:

$Q_{i}$ - the average annual abundance of the largest water flow of a river or lake in a tourist place;

$Q_{W}$ - the average annual abundance of the largest watercourse in the region or country;

$F_{c i}$ - the area of the tourist place;

\footnotetext{
${ }^{4}$ The intensity of relief diversity has the following border values: if $h=1$, dispersion of the relief is small (plains), which is suitable for the excursions; if $h=2$, then the relief is a hilly area, with the possibility of the development of the excursion and recreational activities; if $\mathrm{h}=3$, a relief is highland type, with the possibility of the development of multiple types of tourism (spa, health, rural, etc.); if $\mathrm{h}=4$, the relief is a mountain type with a possible development of the hunting tourism, and if $\mathrm{h}=5$, dispersion of the relief is large (high mountain areas), it is suitable for a health resort, a sporting and recreational activities and adventure activities.
} 
$r$ - the corrective factor (the effect of relief, erosion, people, etc.), whose value must be less than 1. If $r$ was equal to 1, then the waters would depend entirely on them, and their hydrological properties would be ignored and

$c$ - ecological coefficient, which determines water belonging to a given class. ${ }^{2}$

The value of the water resource attractiveness coefficient ranges in the following limits: if $K_{w}=1$, such sites have water resources that allow only simple reproduction; if $K_{w}>1$, there is excessive utilization of water resources and if $K_{w}<1$, water resources allow extended reproduction, which means they are suitable for tourist activities.

(3) The vegetation world, as an attractive tourism value, is assessed, above all, through the attractiveness of the forests, because they are, in fact, the habitat of the animal world. The coefficient of tourist attractiveness of the vegetation world has the following form:

$$
K_{l}=\left(\frac{L_{i}}{L_{c i}}\right)^{\frac{1}{\bar{l}_{s w}}{ }^{\frac{L_{L}}{L_{i}}}}, \text { meaning, } \log K_{l}\left(\frac{L_{i}}{L_{c i}}\right) \log \frac{1}{l} \cdot \frac{L_{s w}}{L_{i}}
$$

wherein:

$L_{i}$ - the area of plant communities in a tourist place (forest, grass, etc);

$L_{c i}$ - the area of the tourist site in hectares;

$L_{s w}$ - the average area of plant communities in that place (per hectare or per capita); and

$l$ - class of forest, which has values from 1 to $5 .^{3}$

The limit values of the coefficient of attractiveness of the plant world are the following: if $K_{l}=1$, forest resources allow only simple reproduction; if $K_{l}>1$, the

\footnotetext{
${ }^{2}$ Ecological coefficient has the following limits: if $\mathrm{c}=1$, waters belong to the 1 class, which means that they are most pure, and may be used for tourism and for the population; if $\mathrm{c}=0,50$, waters belong to the II class, which means that with a little purifying may be used for the tourist industry and the general public; if $\mathrm{c}=0,25$, water belong to the III class, and as such should not be applied in tourism, because they are not for human use and if $\mathrm{c}=0,12$, the waters belong to the IV class and are very contaminated.

${ }^{3}$ The forest class has the following limit values: if $l=5$, then it is I class forests (so-called very good forests, suitable for treatment, hunting, recreation ,etc); if $l=4$, then they are forests of II class (good forest), located at a height of 800 to 1.200 meters above sea level; if $l=3$, it is a III forest class (middle forest); if $l=2$, the forests are IV class (weak forests) and if it is $l=1$, the forests are $\mathrm{V}$ class (very poor forests, not suitable for tourism). From the limit values $l$, we note that for tourism development the most suitable forests are I class forests, so their tourist function and role gradually declines in the lower classes.
} 
forests are at the upper limit of exploitation and their further use would give even more negative results, and if $K_{l}<1$, the exploitation of available forest resources allows extended reproduction, with the possibility of developing different types of tourism.

(4) The assessment of the natural values of a place or region is not complete without a quantitative assessment of the climate. There are two forms used for climate assessment:

(a) Winter season attractiveness index, which has the following form:

$$
K_{z}=K_{h}^{\left(\frac{S_{o}}{S_{i}}\right)^{2}}
$$

wherein:

$S_{o}$ - the average number of days under the snow cover in the region or country,

$S_{i}$ - average length of the snow cover in a tourist place, and

$K_{h}$ - coefficient of economic attractiveness of relief; and

b) The weather index, which takes the form:

wherein:

$$
I=W_{1}+W_{2}+W_{3}
$$

$W_{1}$ - the sum of the average temperatures in the three summer months,

$W_{2}$ - the duration of sunshine in the three-day period, and

$W_{3}$ - the total rainfall in the observed three months.

Econometric models, with due regard for socio-economic factors, determine the possible combination of individual characteristics of different tourist sites. They are, in addition, the basis for planning further development of these sites, with the respect of most important resources in each of them.

The second group of resources of the original tourist offer is made of anthropogenic values. The survey, conducted in Switzerland in the early 1980s, is the best indicator of how important these are for modern tourist demand. According to this survey, $41 \%$ of respondents said they wanted to go sightseeing on their trips to other countries. If we add $10 \%$ of those who exclusively insisted on visits to churches, monasteries, castles, etc, as well as $9 \%$ of those who wanted to be participants in cultural and business events, then we can conclude that about $60 \%$ of tourists want to see anthropogenic values in one country (Milenković, 1999, 51, according to Studienkreis fur Tourismus, Urlaubsreisen, Zurich, 1982). 
Valorisation of anthropogenic tourist attractiveness presents the basis of economic policy in the field of tourism, which should be respected during its organisation, marketing and ecological monitoring.

Anthropogenic values must be considered as the basis not only of the tourist but also of the integral economic development of a country. That is why it is necessary to study in detail all anthropogenic values, both from the aspect of art history, architecture and history, and from the aspect of tourism evaluation.

In addition, it is necessary to find the right complementary measures of the anthropogenic complex with natural tourist motives. First of all, all actions of tourist valorisation must be based on the principles of the active environmental protection concept, because only in that way the purposeful relations of different elements in a given area are established and numerous activities in it could be planned in the long run.

The evaluation of anthropogenic tourism values so far, neither in the world nor in our country, has not been given proper attention. Lately, the method of the current tourism value of anthropogenic attractiveness has been applied, according to which every anthropogenic motive must have its market value and its economic cost. This cost should be included in the price of tourist service providers without official tickets, as a kind of rent only because these motives are in one place and they can be an attraction for urban, educational, prestigious, business, transit, religious and other types of tourism. This means that, depending on their attractiveness and importance to be assessed, anthropogenic attractions should first be divided into main (carrier) and complementary (supplementary). It is necessary, then, to gradually assign to each attraction a certain value: local, regional, national or international.

\section{Geographical-tourist position of Western Serbia}

Geographically speaking, Western Serbia is a space ,...between the lower Sava river and the Drina river, Šmadija and Western Pomoravlje, with a series of microregions: Mačva, Šabačka and Obrenovačka Posavina, Pocerina, Donja Kolubara, Valjevska kotlina and Podgorina, then Jadar, Rađevina, Azbukovica, Lešnica, Tamnava, Ljig... The terrain between the Drina and Šumadija, north of Cer, Vlašić and Ub to Kolubara, makes up the northern half of Western Serbia (Šabac region), and south of the marked line to the breeding of the mountains Povlen, Maljen and Suvobor (towards Zapadno Pomoravlje) constitutes the southern and larger part of Western Serbia (Valjevo region)“(Marković, Pavlović, 1995, 43).

From the administrative point of view, in the area of Western Serbia, the following areas are included: (1) Mačva (Šabac, Loznica, Bogatić, Krupanj, Vladimirci, Ljubovija, Koceljeva and Mali Zvornik), (2) Kolubara (Valjevo, Ub, Lajkovac, Mionica, Ljig and Osečina), (3) Zlatibor (Užice, Prijepolje, Požega, Priboj, 
Bajina Bašta, Sjenica, Arilje, Nova Varoš, Čajetina and Kosjerić) and (4) Moravica (Čačak, Gornji Milanovac, Ivanjica and Lučani).

Taking into account all four areas together, Western Serbia has an area of $14.900 \mathrm{~km}^{2}$, while the number of inhabitants, according to estimates, in the mid2015 , is 938.165 . The population density is 63 inhabitants per $1 \mathrm{~km}^{2}$.

Table 1. Basic demographic data for Western Serbia and its area

\begin{tabular}{||c|c|c|c|c||}
\hline $\begin{array}{c}\text { Western Serbia and } \\
\text { its region }\end{array}$ & $\begin{array}{c}\text { Area in } \\
\mathbf{k M}^{\mathbf{2}}\end{array}$ & $\begin{array}{c}\text { Population on } \\
\mathbf{3 0 . 0 6 . 2 0 1 5 .}\end{array}$ & $\begin{array}{c}\text { Population } \\
\text { density }\end{array}$ & $\begin{array}{c}\text { Number of } \\
\text { settlements }\end{array}$ \\
\hline Western Serbia & 14.900 & 938.165 & 63 & 1.091 \\
\hline 1. Mačva district & 3.270 & 288.034 & 88 & 228 \\
\hline 2. Kolubara district & 2.474 & 168.290 & 68 & 218 \\
\hline 3. Zlatibor district & 6.140 & 276.210 & 45 & 439 \\
\hline 4. Moravica district & 3.016 & 205.631 & 68 & 206 \\
\hline
\end{tabular}

Source: Republički zavod za statistiku (2016). Opštine i regioni u Republici Srbiji 2016, Opšti podaci, Beograd, pp. 18-19.

The geographical position of Western Serbia is very favourable, because a large frequency of people and goods takes place over its territory that positively reflects on, among other things, the tourism development.

According to this, the area of Western Serbia has a very good tourist position towards the main tourist destinations and the main tourist dispersions, both in our country and abroad, and therefore, it has great opportunities to valorise its tourist values.

\section{State of the natural resources of Western Serbia}

Natural resources, which Western Serbia possesses, present the basis for studying its diverse tourism values. This area has rich relief, climate, water and forest potentials. In fact, Western Serbia, having in mind the natural characteristics, as well as the configuration of the soil itself, encompasses the hilly-mountainous area, which forms the predominant part of the wider area of the Starovlak Mountains (Dinić, 1997, 47).

The relief of this part of Serbia, which is formed by action of endogenous and exogenous forces, has complex morphological and morphogenetic properties. His mountains are broken down by valleys and slightly tilted to the north and east.

In its largest part, Western Serbia has a moderate-continental climate. The summers are moderately warm, and the winters are moderately cold, while the transient seasons are mild. Moderate-continental climate is present in the mountains up to 1.000 meters above sea level, and over 1.000 meters is a subalpine climate (Jovičić, 2009, 79). 
For the analysis of temperature in the area of Western Serbia, the official data of the Hydrometeorological Institute of Serbia have been used, measured at meteorological stations in Loznica (at height above sea level of 121 meters) and Zlatibor (at height above sea level of 1.128 meters), for the reference period from 1981-2010.

Graph 1. Maximum, minimum and medium air temperature $\left({ }^{\circ} \mathrm{C}\right)$ for the reference period 1981-2010 at the meteorological station in Loznica

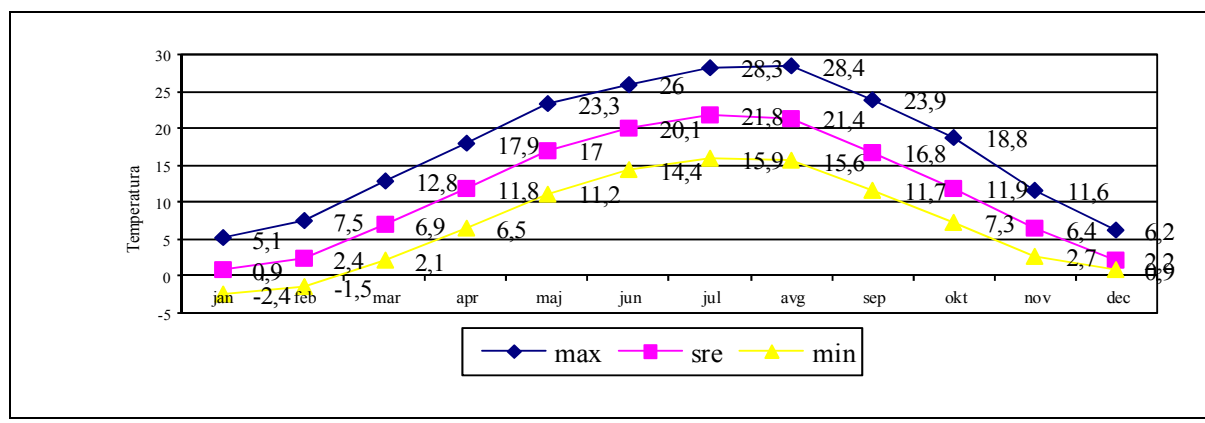

Source: Republički hidrometeorološki zavod Srbije (2016).

Klimatske karakteristike Srbije. Beograd.

The data from the meteorological station Loznica, for the mentioned period, indicate that the medium annual air temperature is $11,6{ }^{\circ} \mathrm{C}$, while July is the warmest month with a medium temperature of $21,8{ }^{\circ} \mathrm{C}$, and the coldest January with $0,9^{\circ} \mathrm{C}$.

Graph 2. Maximum, minimum and medium air temperature $\left({ }^{\circ} \mathrm{C}\right)$ for the reference period 1981-2010 at the meteorological station Zlatibor

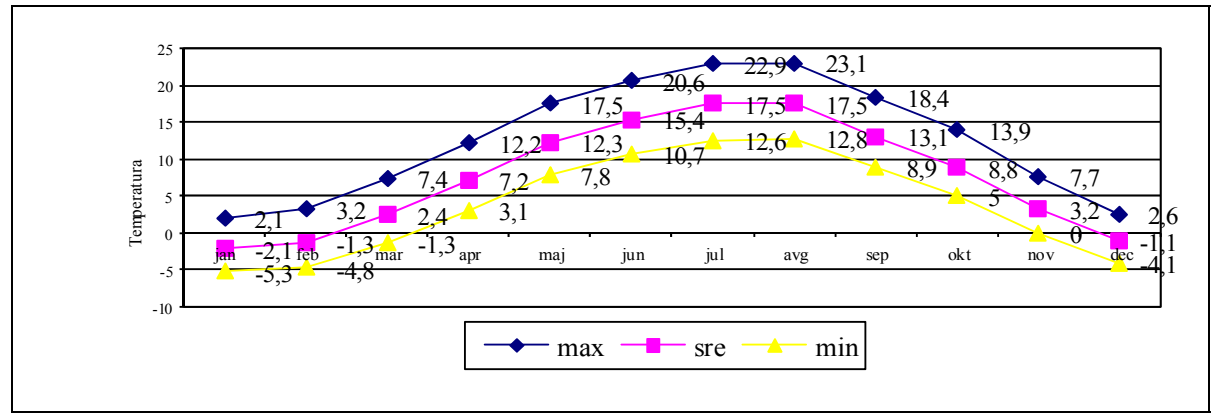

Source: Republički hidrometeorološki zavod Srbije (2016).

Klimatske karakteristike Srbije. Beograd.

According to data from the Zlatibor meteorological station, for the same period, we see that the medium annual air temperature is $7,7^{\circ} \mathrm{C}$, with July and August as the warmest months with a medium temperature of $17,5^{\circ} \mathrm{C}$, while the coldest is January with $-2,1^{\circ} \mathrm{C}$. 
Comparing the data from these two stations, we can conclude that the temperature in the mountainous parts of Western Serbia, in the summer months, is about $4{ }^{\circ} \mathrm{C}$ lower than in the plains, while in the winter months this difference is somewhat lower (about $3{ }^{\circ} \mathrm{C}$ ). As we can see, the medium temperature differences do not show great fluctuations. However, a part of Western Serbia (the so-called Pešterska visoravan) has a specific climate. In fact, Sjenica, has a special type of continental climate with extremely high temperature differences during the year, where the winters are extremely cold and long. For this reason, this region is often called the Balkan Sibir, because in it, in Karajukić Bunari (right at Sjenica), on January 29,1987 , the absolute lowest temperature $\left(-39,5^{\circ} \mathrm{C}\right)$ was measured from the beginning of instrumental measurements in the territory of Serbia (Republički hidrometeorološki zavod Srbije, 2016).

The hydrographic potentials of Western Serbia are extremely large and are reflected in larger and numerous smaller rivers, artificial and natural lakes, as well as mineral and thermomineral sources.

The largest rivers in the area of Western Serbia are the Sava and the Drina. The Sava is the largest and most important hydrographic facility and the largest river flowing into the Danube in the territory of Serbia (Grad Šabac, 2011, 10). Unlike Sava, which is a larger, slower and navigable river, the Drina is a smaller and faster river with a large number of meander and branches in its lower course. The hydroelectric potential of this river is about $20 \%$ of the total potential of our country (Opština Ljubovija, 2013, 9). The Sava and Drina watercourses, as well as other smaller rivers (West Morava, Kolubara, Jetinja, etc.), represent a large hydro energy resource, which has not yet been sufficiently exploated.

The hydrological potential of Western Serbia includes both natural and artificial lakes: Perućac, Zaovine, Vrujci, Zlatarsko, Sjeničko, Ribničko, Radonjsko, Parmeničko, as well as many others. This potential is complemented by mineral and thermo-mineral springs: spas such as Koviljaca, Badanja, Vrujci, Vapa, Ovčar, Trepča and others. Regarding the quantity and quality of underground waters, the richest area not only in Western Serbia, but also on the country level is the area of the Mačva Plain. „Exploratory reserves of the phreatic groundwater of Mačva range at the level of $4,1 \mathrm{~m}^{3} / \mathrm{s}$, which is double the amount of the estimated needs of the region. As it is a natural chemical-bacteriologically correct water (over $20 \mathrm{~m}$ deep), there is a possibility of bottling an incredible 2.000 1/s or about 170.000.000 1/day“" (Grad Šabac, 2011, 10).

Western Serbia, as mostly hilly and mountainous area, has preserved the richness of dense forests and other plant species. In this part of Serbia, dominate oak forests, cherries, grass, black ash and beech. Of all plant species, which are different and numerous and characteristic for the so-called Balkan biogeographical area, one should be isolated as the endemic species - Serbian spruce Pančićeva omorika (Gajić, 1989, 58). 
A diverse fauna is growing on the rich flora of Western Serbia. It is made up of numerous wild animals that are permanently inhabited or occasionally appear. They are divided into large and small wild animals, and some of these species are under the protection of the state. Most common big wild animals are: deer, wild boar, wolf, fox, deer and others. The most widespread small wild animal is the rabbit, and the most common is pheasant, quail, dove, and wild goose. Zlatibor is one of the few mountains in which, somewhere in hidden places, a bear can be found. In this mountain, only here, you can see a free flight of eagle crust or griffon soup, feathery predators that are almost completely exterminated elsewhere.

\section{Variety of anthropogenic potentials of Western Serbia}

In the area of Western Serbia, the traces of old European cultures and civilizations are encountered, such as: ancient Greek, Roman, Orthodox Byzantine, patriarchal Balkan etc. They, of course, had an influence on folk creativity, architecture, way of life and work. In this part of Serbia, some cultural monuments belong to the highest architectural, creative and artistic values of our cultural heritage.

The oldest archaeological sites are the remains of Roman and Byzantine settlements. At Todor (the highest peak of Cer) there are the remains of the Roman Kostantin town and the Byzantine fortifications on Konjuša and Trojan (Ristanović, Gajić, Vujadinović, 2002, 114). Near Šabac, there is a monument to Karađorđe and Serbian heroes from the First Serbian Uprising and the Museum of the Battle of Mišar (at Mišar). The most important monument is located in the city itself on the banks of the Sava River, at the Old town site. These are the remains of the Turkish fortress, built on the Sava border. Šabac fortress is one of the most beautiful in Serbia, so it is categorized and registered as a monument of great social significance.

In Valjevo, the oldest preserved building, Muselim Konak, is distinguished as a typical example of Turkish architecture from the 18th century (Grad Valjevo, 2010, 16). In addition, one of the symbols of Valjevo is Tower Nenadović, built in 1813 for the purpose of defending the city from the Turks. In the city there is the Cathedral Church, the central church of the Valjevo Diocese, as well as the Valjevo Church, built in the period 1836-1856, which is a rare example of a monumental classical building in Serbia.

In Užice, in particular, the memorial complex Kadinjača, dedicated to the fighters of the Užice Labour battalion, who sacrificed themselves in 1941, stands out, protecting the majority of the partisan forces from Užice to Sandžak (Poznanović, 10). The old town, the so-called Užice Fortress, lies on a rocky ridge, which is surrounded by Đetinja on three sides. The position of the city for centuries has provoked the admiration of travelers, passing by its ramparts. However, the first reliable historical sources about the Užice Fortress date back to the middle of the 14th century (Marković, 2014, 246). 
One of the most important monuments of Serbian cultural heritage is located in Prijepolje. This is Mileševa Monastery, where the famous "White Angel" fresco is located. In the 16th century this monastery had a school and a printing house and was one of the centres of Serbian literacy (Kancelarija za lokalni ekonomski razvoj, 2010, 37).

Near Čačak, a special place in the monument's heritage presents a group of ten monasteries, known as the „Little Serbian Holly Mountain“. These are Ovčar-Kablar monasteries "On the right side of the Morava are Vavedenje, Vaznesenje, Preobraženje, Sretenje and Sveta Trojica and on the left Blagoveštenje, Ilinje, Jovanje, Nikolje and Uspenije. In the literature, the monastery of Sv. Georgija is also well known. His seal is in the National Museum in Belgrade" (Stanković, 2002, 29).

In the Ivanjica region, the monuments which are raised along the roads and crossroads, as well as in the church ports, in the cemeteries and around them, have a significant monumental value. The specificity of these monuments is that they, as a rule, mark empty tombs, which means that the deceased is not buried there. They were, usually, intended for warriors who lost their lives across the Balkan Peninsula, buried in the Ionian Sea („Blue Tomb") or were killed in European camps, fighting for the freedom of our people. These monuments were made of sandstone, in which, most often, the entire figures of warriors were carved (Popović, 1996, 259).

Near Gornji Milanovac, on the southern slopes of Rudnik, there is the monastery Vraćevšnica, a monument placed under the protection of the state. To the north of the church is Milošev konak, where in 1818, Miloš Obrenović held a National Assembly where it was decided that the capital of the liberated Serbia would be Kragujevac. Worthy of mentioning, are the remains of Ostrvica, a medieval town built on the extinguished volcanic magma at a hardly accessible peak with a great view of the wavy Šumadija (Ponjavić, 2003, 51). In addition, the authors especially emphasise the Memorial park Brdo mira, a memorial complex that includes: the mausoleum of fallen Red Army soldiers and fighters of Takovo region, a memorial to internees killed in Norway, a memorial to inmates who were killed in Mauthausen and a memorial to fighters who disappeared in the conflicts in the territory of the former Yugoslavia from 1991 to 1999. (Turistička organizacija opštine Gornji Milanovac, Internet address).

A large number of events are held annually in the area of Western Serbia. According to the event calendar of the Tourist Organization of Serbia, in relation to the total number of events in Serbia (around 600), the area of Zlatibor (about 40) and Moravica (about 30) present 12\% (Turistička organizacija Srbije, Internet address). The most famous manifestation of Western Serbia is the Trumpet Festival, which has been continuously held in Guča from 1961 to the present day. Today, the Trumpet Festival has grown to become one of the world's largest music festivals, which gathers over half a million visitors from different parts of the world every year. 
In Šabac, the most famous manifestations are Čivijada and Šabac Fair. Čivijada is a cultural and tourist event that fosters the original humor of the people from Mačva, Posavotamnava and Pocerina, as well as the town of Šabac. The Sabac Fair is an authentic Šabac tradition, what made Šabac famous were the lyrics of the song „Let's go to Šabac to the fair“" (Turistička organizacija grada Šapca, Internet address).

The most famous and most massive manifestation related to the city of Loznica is the Drina regatta. It moves from Mali Zvornik to Banja Koviljača, the beach Žića - the favourite beach of the inhabitants Loznica and Banja Koviljača. Through Drina stretches a vast column of various vessels, and a delightful descent lasts for hours (Zanimljive Destinacije, Internet address).

The largest and most massive manifestation in the Valjevo region is the Tešnjar Nights, which has traditionally been held since 1987. Tešnjar is the old part of the city, which is located along the right bank of Kolubara with a preserved ambient environment from the XIX century. The manifestation includes: theater performances, performances of cultural and artistic societies, concerts of classical, spiritual, rock and folk music, literary evenings, exhibitions of medicinal herbs, pet exhibitions, tasting and selection of the best brandy, etc (Profil Grada Valjeva, 110).

Every year in Ljig, one of the oldest manifestations in Serbia is held - Mowing on Rajac. As a traditional manifestation symbolically represents a pray and the festive ending of the mowing of mountain meadows. Mowing is not just a mowing competition, it's a display of tradition, starting from a gathering of the mowers, water carriers, trumpeters, the start of mowing, the traditional lunch on the grass. The optimal altitude $(600-800 \mathrm{~m})$, pleasant, healing and sedative climate, the richness of anthropogenic tourist potentials have determined that this area was put under state protection in 1963 and declared a regional nature park (Kosidba na Rajcu, Internet address).

The oldest manifestation on Zlatibor is the Traditional Trumpet Festival and the Festival of Folk Creation. It is a musical event, based on ethnographic motives of folk music. This is a qualifying competition for the Guča Festival. Music of trumpet orchestras, specific for Western Serbia, fits into an integral product of Zlatibor, conceptually based on the preservation of folk tradition.

In addition to the diverse cultural and manifestation content, tourists can also be presented with ethnographic values in Western Serbia: folk architecture, old crafts, culinary art, natural rarities, etc.

National architecture is specific to the mountainous area of this region. The houses were built of stone, logs, wattle and daub or a combination of materials semi-log cabins or wattle cottages. An authentic example of such architecture is the castle of Duke Miloš in Gornja Crnuća, in the municipality of Gornji Milanovac, dating from 1814, which is under the protection of the state. The most important and the most widespread type, typical for Western Serbia is the house known as 
„osaćanka“, by the masters from Osat in East Bosnia. In the mid-18th century they came to these parts to build cottages, and then they remained on the property they occupied (Perišić, 2002, 107).

Old crafts are becoming extinct everywhere, even in Western Serbia. There were various craftsmen in this area: shoemakers, bakers, blacksmiths and others. That's why the handicrafts of old crafts can be seen in many houses, such as: bučuk - a food container, zastrug - a container with a food feed lid, testija - a jug with a tap for drinking water, etc. The old crafts should also include kazandžije - brandy still makers, because Western Serbia has been known for good brandy for years.

Culinary can, to a large extent, contribute to the creation of a more complex and subtle tourist offer. The cuisine of this part of Serbia has enough specificity that could attract tourists more. These are: dishes in a clay pot (sač), grilled dishes, roasting, home-made bun, soup (beans, cabbage), homemade brandy and others.

Among natural rarities, we especially point out the individual centuries-old trees of the linden and black locust in Mačva. They serve only as witnesses of the former forest cover in this area. They are under the protection of the state, such as the oak trees in the settlements of Sovljak and Šabac (known as Žakica), the Karađorđe oaks in Trbušac, the linden tree in Glogovac and the so-called „Karađorđe linden tree“ in Slepečević. Unique specimens are wood „Janj“ and six old oaks „Geratović bush“ in Drenovac (Grčić, 2003, 59).

Taking into account the cultural-historical, manifestation and ethnographic values of Western Serbia, we can conclude that it presents a valuable gathering of attractiveness, which can be presented to modern tourists.

\section{Research results}

Applying the above mentioned econometric methodology, they have carried out the evaluation of natural attractions: relief, hydrographic potentials (water resources), plant life (flora and fauna), as well as climate, for the needs of development of tourist activity in the area of Western Serbia, or in its areas.

The procedure of using econometric methods will be shown on the example of a coefficient of tourist attractions of the relief, for the Mačva region. Let Šabac be a tourist place in this area (Novović, Dugalić, 2016, 106). Now the authors need to determine the maximum and minimum altitude for this place. Maximum altitude $\left(H_{i}\right)$ in Šabac is the settlement Bukor at 300 meters, and the minimal altitude is Mišar settlement at 80 meters (Stamenković, 2001). The difference between these two heights is the maximum difference in altitude $\left(H_{w i}\right)$ in Šabac, which is 240 meters (300-80). By the same principle, the authors determine the maximum and minimum altitude for the wider zone, that is, for the Mačva region. Maximum 
altitude $\left(H_{m}\right)$ of this area is the highest peak of Mountain Bobija (Tornčka Bobija) at 1,272 meters, and the minimum altitude is settlement Beljin at 75 meters in Vladimirci (Stamenković, 2001). The difference between these two heights is the maximum difference in altitude $\left(H_{w}\right)$ of the Mačva region and it is 1,197 meters $(1,272-75)$. Finally, we need to determine the intensity of the relief division for the Mačva region, which is a hill type, which means that $h=3$. On the basis of these elements we calculate the coefficient of tourist attraction of relief $\left(K_{h}\right)$ for the Mačva region:

$$
K_{h}=\left(\frac{300}{1.272}\right)^{\frac{1}{3} \cdot \frac{1.197-240}{1.197}}=0,24^{0,27}=0,68
$$

By the same procedure, the authors determine this coefficient for the other three areas of Western Serbia. Due to the extensiveness and other coefficients of valorisation of natural resources, as well as due to the spatial limitations of work, the following table gives only their final values.

Table 2. Tourist evaluation of natural attractions for the regions of Western Serbia, according to econometric models

\begin{tabular}{|l|c|c|c|c|c|}
\hline Western Serbia region & $K_{h}$ & $K_{w}$ & $K_{l}$ & $K_{z}$ & $I$ \\
\hline Mačva & 0,68 & 0,89 & 0,71 & 0,74 & 621 \\
\hline Kolubara & 0,75 & 0,78 & 0,62 & 0,75 & 629 \\
\hline Zlatibor & 0,86 & 0,53 & 0,84 & 0,91 & 582 \\
\hline Moravica & 0,93 & 0,67 & 0,87 & 0,89 & 591 \\
\hline Western Serbia (average) & 0,81 & 0,72 & 0,76 & 0,82 & 606 \\
\hline
\end{tabular}

As we can see, the coefficient of attractiveness of the relief for other areas of Western Serbia is less than 1, which means that they are suitable for the development of various tourist activities. As this value approaches 1, these are spaces suitable for the development of winter, skiing and adventure tourism. Such areas are present on Zlatibor, Zlatar, Tara, Golija and Rudnik.

Since the division of relief in Western Serbia is of different intensity (hilly, mountain and mountainous), this means that such terrains are suitable for development of spa, health, rural tourism, but also many others: sports-recreational, excursion, business- research, speleological, etc.

The coefficient of tourist attraction of water resources $\left(K_{w}\right)$ for the regions of Western Serbia shows values that are less than 1. By classifying them according to qualitative groups, the waters in this area belong to the first, second and third class. The first qualitative group $(c=1)$, includes thermomineral waters and upper flows of rivers, especially smaller ones (Đetinja, Moravica, Rzav and similar). The second 
qualitative group $(c=0,50)$ includes the middle currents of the Sava, the Western Morava, Kolubara, then the middle and lower streams of the smaller mountain rivers, as well as the waters of all the lakes. The third qualitative group $(c=0.25)$ consists of water that is in the urban areas or in contact with polluting industrial plants, and there are very few. From this analysis we can conclude that the waters in this part of Serbia are suitable for drinking, treatment and bathing, or they can have a therapeutic and recreational purpose. In addition, the Sava and Drina rivers have the greatest importance for the development of tourism, primarily due to the provision of conditions for various types of water sports. Therefore, Western Serbia should put more emphasis on the development of various types of tourism on the water: fishing, nautical, river, bathing, sports-recreational, rafting, etc.

The coefficient of tourist attractiveness of the plant world $\left(K_{l}\right)$, for the area of Western Serbia has values that are also less than 1. Zlatibor, Tara, Rudnik, Golija, Javor and other mountains are rich in forests, meadows, pastures and fields. In addition, a variety of game-wild animals inhabits these lands. Forests belong to I and II class (very good forests $l=5$ and good forests $l=4$ ). Therefore, the flora of this area is important for excursion, sports and recreational, eco, ethno, health, and hunting tourism. The best conditions for this have mountains Zlatibor, Tara and Golija because, according to the floristic composition, they present the most complex biocenoses. These spacious forest complexes have numerous rivers, suitable for excursion-recreational and health-resort tourism movements, as well as hunting and fishing.

The winter season attractiveness coefficient $\left(K_{z}\right)$ for all areas of Western Serbia shows values that are less than 1 , which means that they, especially Zlatibor and Moravica, are suitable for more intensive development of all forms of winter tourism, primarily skiing.

The values of the weather index in summer $(I)$ for Western Serbia areas range from 580 to 620 , which is within the optimal range. From the aspect of the main (summer) season, this area of Serbia is suitable for all forms and types of tourism, and for this reason the tourist offer should be expanded in the off-season. Then, the spa and air sanatoriums would become more significant, then the development of rural, ecological, manifestation, hunting and fishing, as well as many other types of tourism would also expand.

In addition to various natural resources for the development of tourist activity, Western Serbia has rich anthropological heritage. The complex cultural and historical heritage, ethnographic values and numerous manifestational contents represent a very good basis for the development of various types of tourism in this area. By developing religious, cultural, manifestational and other types of tourism, Western Serbia can acquire significant advantages over the regions in the surrounding. In order to achieve this, its anthropogenic attractions have to be evaluated from several aspects. 
Table 3. Tourist evaluation of anthropogenic attractiveness in Western Serbia

\begin{tabular}{|c|c|c|c|}
\hline $\begin{array}{c}\text { Main (leading) } \\
\text { attractions }\end{array}$ & Significance & $\begin{array}{c}\text { Complementary (additional) } \\
\text { attractions }\end{array}$ & Significance \\
\hline \multicolumn{4}{|c|}{ 1. Cultural and historical heritage } \\
\hline $\begin{array}{l}\text { Ovčar-Kablar } \\
\text { Monasteries }\end{array}$ & International & Log Church in Takovo & National \\
\hline Manastery Mileševa & National & Manastery Kovilje & Local \\
\hline Manastery Tronoša & Regional & Spomenici krajputaši & Local \\
\hline $\begin{array}{l}\text { Temple of } \\
\text { Vaznesenja } \\
\text { Hristovog }\end{array}$ & Regional & Kosana town & Regional \\
\hline $\begin{array}{l}\text { Manastery } \\
\text { Vraćevšnica }\end{array}$ & National & Šabac fortress & Regional \\
\hline $\begin{array}{l}\text { Memorial complex } \\
\text { Kadinjača }\end{array}$ & National & Muselim castle & Local \\
\hline $\begin{array}{l}\text { Memorial park Brdo } \\
\text { mira }\end{array}$ & International & Užice fortress & Regional \\
\hline $\begin{array}{l}\text { Monument to the } \\
\text { warriors in the First } \\
\text { World War }\end{array}$ & International & Ostrvica & Local \\
\hline $\begin{array}{l}\text { Memorial complex } \\
\text { The second Serbian } \\
\text { rising }\end{array}$ & International & Roman bridge & Local \\
\hline \multicolumn{4}{|c|}{ 2. Manifestational values } \\
\hline Trumpet Festival & International & Šabački vašar & Regional \\
\hline Čivijada & Nacionalni & Vuk convocation & Regional \\
\hline Drina regatta & International & Prum fair & Regional \\
\hline Tešnjar nights & Nacionalni & Days of Lajkovac & Regional \\
\hline $\begin{array}{l}\text { International festival } \\
\text { of children folk } \\
\text { dance ra }\end{array}$ & International & Mowing on Rajac & Regional \\
\hline Kustendorf & International & Festival of fifers & Regional \\
\hline Nušićijada & National & Ravna Gora Assembly & National \\
\hline \multicolumn{4}{|c|}{ 3. Ethnographic wholes and features } \\
\hline Castle of Duke Miloš & National & Houses Osećanke & National \\
\hline $\begin{array}{l}\text { House of Yugoslav- } \\
\text { Norwegian } \\
\text { friendship } \\
\end{array}$ & International & Mills & Local \\
\hline Culinary & International & Craft handicrafts & Regional \\
\hline Caves & International & National folk costumes & National \\
\hline
\end{tabular}

According to the first aspect, it is necessary to distinguish the main, or leading anthropogenic attractions. These attractions are the basic form of tourist offer (pole of development), so, therefore, affect the overall physiognomy of the given area 
and are important profit makers. They are the itinerary of tourist movements of one area and according to them the redistribution of other tourist motives is conducted. This would be in Western Serbia, above all, Ovčara-Kablar Monasteries and the Trumpet Festival in Guča.

In the second aspect of evaluation, it is necessary to determine complementary or additional anthropogenic attractions, for example: archaeological sites, fortresses, churches, ethno villages, museums, memorials, cultural events, etc.

When we sort the anthropogenic attractions to the main and the complementary, in the next step, it is necessary to determine the appropriate significance for each of them: international, national, regional or local. For example, the Ovčar-Kablar Gorges have an international value, the Log Church in Takovo is a national, and the monuments along the roads are of local significance

The anthropogenic heritage of Western Serbia, still, has not been properly tested and valued. We believe that such an evaluation of anthropogenic tourist attractions can create greater opportunities for extensive tourist visits to this part of our country. In doing so, it is necessary, whenever possible, to evaluate the value of anthropogenic attractions in collaboration with natural resources. Their combination in the world represents the so-called integral tourism, where all attractive elements are included in the offer of an area. For example, Ovčar-Kablar Monasteries are gaining more tourist value if they include spa tourism in Ovčar Spa and the banks of Gornja Trepča. In addition, anthropogenic tourism motives should be observed as independent or as inseparable parts of the wider entireties. Independent tourist motives can be monasteries, manifestations, ethno-villages and similar, which means that they can be presented to tourists individually or separately. On the other hand, anthropogenic motives that cannot function independently should be included in the overall tourist offer of a place. For example, certain memorials or monuments along the roads in one place should be viewed as components of a more significant type of tourism that is developing in that area. In the end, for the quality evaluation of anthropogenic attractions in Western Serbia, one should bear in mind the following: if the motives are closer to populated places, urban units, or are located on the main directions of tourist movements, their value is greater then.

The evaluation of the resources of the original tourist offer of Western Serbia shows that they all have very good quality, which can enable the development of different types of tourism. It is necessary, in addition, to identify those types that will be drivers or poles of development of tourist activity in this area. This development, of course, should be in accordance with the principles of sustainable development, that is, in the function of preserving the environment. Therefore, consideration of the possibilities of exploiting natural and anthropogenic potential, as well as their valorisation in the right way, is only a preliminary step towards the formation of a new comprehensive strategy of tourism development of Western Serbia. 


\section{Conclusion}

Western Serbia possesses significant natural and anthropogenic resources, which can be used for tourist purposes. Natural resources are characterized by a variety of relief structures, a very favorable climate, a wealth of hydrological potential, as well as a variety of plant and animal life. Anthropogenic resources are reflected in rich cultural and historical heritage, numerous manifestation and exceptional ethnographic values. Due to this condition, the resources of the original tourist offer provide a very good basis for the development of various types of tourism: ecological, rural, spa, hunting, fishing, mountain, health, excursion, manifestation, religious etc.

Under such conditions, Western Serbia can satisfy the diverse needs of modern tourism demand, and the consideration of the possibility of exploiting its natural and anthropogenic potential for tourist purposes is of particular importance for starting the development of tourist activity in this area.

The market evaluation of natural resources of Western Serbia has confirmed that it is possible to develop different types of tourism in this area, since the calculated values of econometric coefficients range from 0 to 1 . Valorisation of anthropogenic attractions has been carried out from several aspects. It is essential that in the first step they are divided into the main and complementary, and that later, to each of them was given a certain gradation character. Regardless of whether they now have local, regional, national or international importance, they can be put into the function of developing various tourist activities. But this requires detailed studies of all anthropogenic values, both from the aspect of the history of art, architecture and history, and from the aspect of tourism valuation.

Anthropogenic values, although not sufficiently valorised for now, must also be considered as the basis for the integral tourism development of Western Serbia. This implies finding the right complementary measure of the anthropogenic complex with natural tourist attractions. For example, religious tourism can be linked to spa, mountain and manifestation tourism, because every place in this part of Serbia, which is predominantly mountainous and hilly, has certain cultural and historical monuments from the closer or further past, but also the various manifestations that are continuously organized from year to year.

Considering that the area of Western Serbia possesses diverse resources of the original tourist offer, it creates the possibility to accomplish, by evaluating them and presenting them together with modern tourist demand, a better competitive position on the international tourist market, and on the other hand, to achieve significant incomes from development of tourism activities, which can have positive effects, not on the economic but also in the overall social development of Western Serbia. 


\section{References}

Aranđelović, Z., Gligorijević, Ž. (2014): Regionalna ekonomija, Ekonomski fakultet, Niš, Srbija.

Dinić, J. (1997): Prirodni potencijal Srbije - ekonomsko-geografska analiza i ocena, Ekonomski fakultet, Beograd, Srbija.

Gajić, M. (1989): Flora i vegetacija Golije i Javora, Šumarski fakultet, Beograd, OOUR Šumarstvo Golija, Ivanjica, Srbija.

Gligorijević, Ž., Stefanović, V. (2010): Ekonomika turizma, Autorsko izdanje, Niš.

Gligorijević, Ž., Gligorijević, A. (2012): Turizam - karakteristike i perspektive razvoja, SVEN, Niš, Srbija.

Grad Šabac (2011): Lokalni ekološki akcioni plan Šapca, knjiga 2: Akcioni planovi. Grad Šabac, Srbija.

Grad Valjevo (2010): Strategija održivog razvoja grada Valjeva 2010 - 2020. godine, Valjevo, Srbija.

Grčić, M. (2003): Potencijali za razvoj eko-turizma u Donjoj Posavini (Srbija), Glasnik Srpskog geografskog društva, Geografski fakultet, 83(1), str. 57-64, Beograd, Srbija.

Jovičić, D. (2009): Turistička geografija Srbije. Geografski fakultet, Beograd, Srbija.

Kancelarija za lokalni ekonomski razvoj (2010): Strategija održivog razvoja opštine Prijepolje (2011-2015), Prijepolje, Srbija.

Marković, J. Đ., Pavlović, M. A. (1995): Geografske regije Jugoslavije (Srbija i Crna Gora). Savremena administracija, Beograd, Srbija.

Marković, S. (2014): Osnovne karakteristike demografskog razvoja Užica do XX veka, Demografija - međunarodni časopis za demografska i ostala društvena istraživanja, Geografski fakultet, (11), str. 245-257, Beograd, Srbija.

Milenković, S. (1999): Turistička aktivnost u tržišnoj privredi, Vuk Karadžić, Paraćin, Srbija.

Milenković, S. (2000): Resursi u ekonomiji, Ekonomski fakultet, Kragujevac, Srbija.

Novović, M., Dugalić, N. (2016): Ekonomsko vrednovanje turističkih resursa Zapadne Srbije u funkciji razvoja turizma, Modern Management Tools and Economy of Tourism Sector in Present Era. International Thematic Monograph: Thematic Proceedings, Association of Economists and Managers of the Balkans, Belgrade in cooperation with the Faculty of Tourism and Hospitality, Ohrid, Macedonia.

Opština Ljubovija (2013): Strategija lokalnog održivog razvoja opštine Ljubovija za period 2013 - 2022. godine, Ljubovija, Srbija.

Perišić, Ž. (2002): Vreme imenom zapisano: Rudničko-takovski kraj, Litopapir, Čačak, Srbija.

Ponjavić, V. (2003): Moj zavičaj: vodič kroz opštinu Gornji Milanovac, Dositej, Gornji Milanovac, Srbija.

Popović, V. I. (1996): Opština Čačak - geografska proučavanja, Litopapir, Čačak, Srbija.

Republički hidrometeorološki zavod Srbije (2016): Klimatske karakteristike Srbije, Beograd, Srbija.

Republički zavod za statistiku (2016): Opštine i regioni u Republici Srbiji 2016., Opšti podaci, Beograd, Srbija.

Ristanović, B., Gajić, M., Vujadinović, S. (2002): Turistički potencijali Šabačkog kraja, Zbornik radova Departmana za geografiju, turizam i hotelijerstvo, br. 2., str. 109118., Novi Sad, Srbija. 
Stamenković, S. (2001): Geografska enciklopedija naselja Srbije, Geografski faklutet, Beograd, Srbija.

Stanković, S. (2002): Turizam Srbije, Srpsko geografsko društvo, Beograd, Srbija.

Warszynska, J. (1974): Ocena zasobow srodowiska naturalnego, Panstwowe wydawnictwo naukowe, Warszawa, Krakow.

Kolubarski upravni okrug, available at: http://www.kolubarski.okrug.gov.rs/

Kosidba na Rajcu, available at: www.kosidba.com/rajac.html

Mačvanski upravni okrug, available at: http://macvanski.okrug.gov.rs/macokr/index.php/homepage

Moravički upravni okrug, available at: http://moravickiupravniokrug.org/

Poznanović, R. Istorijski i kulturni spomenici (1945-1975). Užice nekad $i$ sad, available at: http://www.graduzice.org/userfiles/files/istorijskiikulturnispomeniciod1945do1975.pdf

Profil Grada Valjeva, Odsek za lokalni razvoj i privredu, available at: http://www.valjevo.rs/Dokumenta/GradValjevo/Brosure/cd/Profil\%20Grada\%20V aljeva.pdf

Turistička organizacija grada Šapca, available at: http://sabacturizam.org/?page id=1577

Turistička organizacija opštine Gornji Milanovac, available at: http://www.togm.org.rs/spomenici/brdo-mira

Turistička organizacija Srbije, available at: http://www.serbia.travel/dogadjaji/kale-ndardogadjaja.36.html

Zanimljive Destinacije, available at: http://www.zanimljivedestinacije.info/lepotesrbije/221-loznica-i-okolina-podrinjska-lepotica.html

Zlatiborski upravni okrug, available at: http://www.zlatiborskiokrug.net/index.html

\section{VALORIZACIJA RESURSA IZVORNE TURISTIČKE PONUDE ZAPADNE SRBIJE}

Apstrakt: Poslednjih decenija, posmatrano u svetskim razmerama, turistička tražnja postaje sve više izdiferencirana. $\mathrm{Na}$ jednoj strani, traži se očuvana prirodna sredina i čist vazduh, dok, na drugoj strani, sve veći broj turista želi da na putovanju i odmoru razgleda kulturno-istorijsko nasleđe područja u kome provodi odmor. Da bi neko područje moglo da konkuriše na svetskom turističkom tržištu, mora da poseduje raznovrsne i obimne resurse. Traže se, dakle, nove destinacije koje, pre svega, poseduju bogatu izvornu turističku ponudu. Budući da Zapadna Srbija raspolaže značajnim prirodnim i antropogenim resursima, u ovom radu se istražuju njeni izvorni turistički potencijali. U tom smislu, uz primenu savremene metodologije za vrednovanje još uvek neiskorišćenih potencijalnih turističkih prostora, $u$ radu se izlaže jedan pristup valorizaciji, kako prirodnih, tako i antropogenih resursa Zapadne Srbije. Istraživanje ima za cilj da, kroz takvo vrednovanje, pokaže kako i, na koji način, ti resursi mogu biti stavljeni u funkciju turističkog iskorišćavanja i većeg uključivanja Zapadne Srbije u savremene turističke trendove.

Ključne reči: Turizam, ponuda, Zapadna Srbija, resursi, valorizacija. 


\section{Authors' biographies}

Aleksandar Gligorijević is a third-year Ph.D. student, module Macroeconomics, at the Faculty of Economics in Niš. He also works as an auditor at the Supreme Audit Institution of Serbia. Before doctoral studies, his research was focused on regional development of the European Union and tourism as generator of regional development. The most recent programmes he participated in were EBRD Training Programme and IDEA data analysis.

Milan Novović was born on January 5th, 1974 in Ivanjica. He graduated and obtained his master's degree from the Faculty of Economics in Kragujevac, and received his Ph.D. from the Faculty of Economics, University of Niš. He is employed at the Vocational Business School in Belgrade. He has published over thirty papers in scientific and professional journals and has participated in numerous conferences in the country and abroad. 